\section{FOOD PRODUCTION AND NUTRITION}

\author{
By N. W. PIRIE \\ Rothamsted Experimental Station
}

$\mathrm{U}$ NDER the general title "Food Production and Distribution in Relation to Nutritional Needs", the recently established Nutrition Society held a meeting on February 28. Papers were read by Sir John Orr on "The Agricultural Implications of a Food Policy based on Nutritional Needs", by Dr. N. C. Wright on "Rival Claims of Animals and Man for Food", by Mr. E. T. Halnan on "Animals as Food Converters" and by Sir John Russell on "Planning for Agricultural Production". Each paper was followed by discussion, but the subjects of the papers were so closely interlocked that there was considerable overlapping of the points made by the twenty-five contributors to the discussion.

After two and a half years of war there is no evidence of a worsening in our nutritional state. Sir John Orr pointed out that, although there are differences between the feeding standards adopted in different countries and by different authorities, these are differences in detail and, broadly speaking, there is now unanimity. At the outbreak of war, both in Great Britain and in the United States, one third of the population fell below this standard; a decade before that the proportion had been one half. This improvement gives us some cause for satisfaction, but it is clear that in planning post-war nutrition it is insufficient to aim merely at the restoration of the pre-war state. The consumption of foods such as milk might well be increased by 100 per cent in Great Britain, and our agriculture should concentrate on the production of perishable protective foods. In many parts of the Empire, for example India, the need is not confined to special foods, for the nutritional condition is appalling, and more of almost every sort of food is needed.

Both during the War and after it is not sufficient merely to consider which crops should be grown; research is needed on the more efficient utilization of existing crops and on their improvement. Sir John mentioned, as an example of the former, the possibility of extracting edible protein from grass, "an idea started two or three thousand years ago under royal patronage", and as examples of the latter the production of vegetables richer than usual in minerals and of oats and wheat with an enhanced vitamin $B_{1}$ content. The main point brought out in the discussion was the need to ensure that the vitamins originally present in foods such as vegetables are not lost because of the delays in retailing or because of carelessness in cooking. Dr. S. W. Swindells spoke of the "planned destruction of vitamin $\mathrm{C}$ in canteen cooking" and referred to cases in which incipient scurvy, caused by this cooking, had been mistaken for pyorrhea.

Dr. Wright showed, in a number of different ways, that in pre-war farming in Great Britain animals were predominant; for example, the population weighs approximately two million tons and the livestock five, three million acres were devoted to the direct production of human food and twenty-seven to the production of food for animals, besides which the latter ate two thirds of the imports. This state of affairs has come about because most people prefer the flavour and small bulk of foods derived from animals, and in peace-time there is no real competition between man and animals; for we get the better parts of the foodstuffs, whether imported or homegrown, and the animals use up the rest. In war-time this luxury cannot be afforded, for animals rarely have an overall efficiency of more than 25 per cent in the conversion of feeding-stuffs into human food.

The productivity of land devoted to the grazing animal is also low : an acre will yield six million calories in the form of potatoes, or three million in the form of wheat but only one million as milk and 200,000 as meat. The ploughing up of three million acres of grass, 15 per cent of the total, must therefore be accepted as a wise policy and it should be remembered that it amounts only to restoring the agricultural balance that existed in Great Britain sixty years ago. The best land was generally ploughed; the policy therefore led to the loss of about a quarter of the stock-feed produced by grassland. This, together with the restricted importation of feedingstuffs, has reduced the available fodder to one half. In these circumstances Dr. Wright has argued that it would be unwise to divert any more cattle food into human feeding by increasing the percentage extraction of flour. The raising of the extraction rate from 70 to 75 per cent has reduced the supply of wheat by-products by 400,000 tons and a further rise to 85 per cent will reduce it by $1,000,000$. This fascinating, controversial and extremely complicated subject was not, however, argued in any detail at this meeting.

The question of efficiency of conversion of feeding. stuffs into human food was discussed by Mr. E. T. Halnan, Mr. A. N. Duekham, Dr. D. J. Ewing, Dr. J. Hammond, Prof. J. R. Marrack and Prof. D. M. S. Watson. A simple percentage efficiency rarely expresses the matter adequately because many animals can use feeding-stuffs that could, in no circumstances, be used by man. Even when efficiency is considered in terms of protein only, it should be borne in mind that animal proteins are of higher biological value than some of the plant proteins from which they are made. Young pigs and poultry are the only converters that need a type of food substantially similar to that needed by man. Egg production is as efficient as, or more efficient than, milk production and some of the concentrates at present reserved for the dairy cow might well be released for poultry feeding so long as this food is used primarily for eggs and not for table birds. In the allocation of feeding-stuffs more attention should be paid to individual variations between animals. In general, the young animal is a more efficient retainer of protein and the old a more efficient retainer of calories, laid down in the form of fat. Since protein is the primary deficiency in the wartime diet, this would suggest that animals should be slaughtered young, but it can be argued on the other side that the adult pig or ox may be eating food for which there is otherwise no use. So long, therefore, as they are not. allowed to compete with men or with the, at first sight, younger and more efficient producers, there is no objection to their retention as producers of fat.

Having considered, at some length, the question of the animal's efficiency, the meeting turned to a brief consideration of our own. Dr. Marrack criticized the inefficient distribution of milk and pointed out that there are fines for selling milk of low fat content but not for selling milk rich in bacteria or low in vitamin $\mathrm{A}$. The lack of any preventive medicine on 
the farm and the great losses of feeding-stuffs, caused by the prevalence of mastitis and contagious abortion, were stressed by Dr. W. R. Wooldridge. Individual farmers in the same area may get widely different yields with the same crop. Dr. W. K. Slater asked how great the increase in our productivity would be if every farmer were as skilful as the best farmers, but no one was prepared to answer the question.

The various conflicting interests that have conditioned agricultural policy in the past were considered by Sir John Russell. In the first place the cheapest type of farming in Great Britain would be extensive ranching with few workers and much processing ; for, except on a strip up the east coast, our best crops are grass and trees. The essence of planning is that we should decide what is wanted and then guarantee the farmer a market for that crop, otherwise he naturally tends to play for safety and farm in the cheapest way possible. Mr. Halnan had said earlier that the conversion of Great Britain into a "dormitory and exercise ground for animals" is sound economics when imported fodder is cheap, and Dr. F. Yates had explained. how a labour shortage tends to encourage stock-feeding. Under planned agriculture half our food should be home-grown, but this does not mean that half of each particular food should be; there should be a great extension in milk and vegetable production. This would mean a decline in home production of wheat, butter and other commodities that keep well and so can be easily transported from abroad. It was noteworthy that the policy of increasing the wheat acreage, except as a purely war-time measure, found no support from any speaker at the meeting; instead there was substantial unanimity that Great Britain should adopt a policy somewhat similar to the peacetime policy of Denmark.

In summing up the results of the meeting, Sir Joseph Barcroft pointed out that, whereas a Government committee consists of men who have been carefully selected for reasons not always connected with their scientific attainment, it was open to anyone with knowledge to have his views heard at. meetings such as this. He suggested that a channel should be established through which any agreed plan of action could be brought to the attention of the Government. The speakers who had urged on those responsible for the planning of diet the need for making that diet appetizing had his wholehearted agreement. The Society presumably claims no particular originality for this point of view, an earlier authority having remarked:

Now, good digestion wait on appetite, And health on both !

\section{UNITED STATES ANTARCTIC EXPEDITION, 1939-4I}

A SYMPOSIUM on the scientific results obtained $A$ by the United States Antarctic Expedition, 1939-41, was arranged by the American Philosophical Society at Philadelphia on November 21 last.

Prof. F. Alton Wade, professor of geology, Miami University, and senior scientist of the U.S. Antarctic Service, gave an introductory paper, in which he stated that one of the primary purposes of the Expedition was to carry on a comprehensive programme of scientific observations and research. A great portion of the programme was carried to completion by the twenty-one members of the scientific staff; due to an unexpected termination of the expedition, some phases were only partially completed. Detailed observations were made and programmes of research were conducted in the following fields : auroral phenomena, bacteriology, botany, cosmic rays, glaciology, magnetism, medicine, meteorology, mieropalæontology, ornithology, petrography and petrology, physiography, physiology, radio, seismology, structural geology and zoology. Among the reports in preparation are the following: observations and height determinations of the aurora australis; the physiographical features of the Ross Shelf ice; the geology of the Weddell coast of Palmer Peninsula south of $68^{\circ} \mathrm{S}$.; the geological features and formations in the vicinity of East Base; the sedimentary rocks of the Edsel Ford Mountains; the petrography and structure of the Rockefeller Mountains; ornithology report, which will include observations of bird life at both bases, at the Melchior Islands and along the ships' routes; the petrography and structure of the Melchior Islands ; a correlation of radio receiving and transmaitting conditions with magnetic phenomena and auroral displays.

Paul A. Siple, of the U.S. Antaretic Service, said that geographical exploration was carried on from West Base in 1940 by means of five reconnaissance field parties and two aireraft. The routes used followed but extended considerably beyond those opened first by the Byrd Expeditions of 1929 and 1934. The field parties' operations were limited to the hinter-coastal mountains east of Little America from long. $164^{\circ} \mathrm{W}$. to long. $136^{\circ} \mathrm{W}$. The parties were occupied mainly with surveying, geology, biology and meteorology. Aerial reconnaissance and surveying extended east. ward to long. $120^{\circ} \mathrm{W}$., including the major land features to nearly 200 miles south of the coast. This was accomplished by six flights, making more than a thousand usable aerial survey photographs avail. able of the area.

Exploration to the west of Little America included three major flights over previously explored portions of the Ross Ice Shelf, crossing in each case into meridians of east longitude in the vicinity of lat. $78^{\circ} 30^{\prime} ; 79^{\circ} 20^{\prime} ; 81^{\circ} ; 83^{\circ}$; and $84^{\circ}$. Four newly discovered areas of internal disturbance were studied and fifteen bays and inlets were photographed in the continuous aerial survey of about four hundred miles of Barrier face from an altitude of $7,000 \mathrm{ft}$.

Southern exploratory operations were confined mainly to filling in the gap of mountains in the Austral Cordillera between Beardmore and Live Glaciers. However, the character of land formations east of the 120 th meridian west indicated that there is no sea-level connexion between the Ross and Weddell Seas.

Other geographical accomplishments included glacial studies of the formation and physiography of shelf ice, problems of human adaptation to the climate of Antaretica, and studies of the cooling power of the wind.

An account of the geology of the large ranges around Little America was given by Lawrence A. Warner, of Johns Hopkins University.

The physical aspects of shelf ice were described by Prof. Alton Wade. The first detailed investigations of shelf ice were made at West Base during 1940. Included in the programme were the following : the variation of the density of the firn with depth, sub. 